\title{
DAKWAH MELALUI BIMBINGAN DAN KONSELING
}

\author{
Muh Fadli Fajrin \\ Sekolah Tinggi Agama Islam (STAI) Darul Dakwah Wal-Irsyad (DDI) Kota Makassar, \\ Indonesia \\ Email: Muhfadlifajrin1234@gmail.com
}

\begin{abstract}
ABSTRAK
Memperbincangkan dakwah melalui bimbingan dan konseling memang adalah hal yang menarik dikalangan para konselor, dimana konselor yang bertujuan memberikan solusi terhadap berbagai masalah kehidupan. Maka dakwah harus dikemas dalam metode yang tepat, yaitu aktual, faktual, dan kontekstual. Aktual dalam arti memecahkan masalah kekinian dalam masyarakat, faktual dalam arti nyata (tidak sekedar teori), tetapi dapat juga di aplikasikan bagi pasien konselor.
\end{abstract}

\section{Kata kunci: Dakwah, Bimbingan, Konseling}

\section{PENDAHULUAN}

Dakwah adalah suatu proses penyampaian, ajakan atau seruan kepada orang lain atau kepada masyarakat agar mau memeluk, mempelajari, dan mengamalkan ajaran agama secara sadar, sehingga membangkitkan dan mengembalikan potensi fitri orang itu, dan dapat hidup bahagia di dunia dan akhirat. ${ }^{1}$ Hakekat yang paling penting adalah adanya keyakinan atau kepercayaan bahwa Allah hanya satu dan tiada satu pun yang dapat menyamai-Nya, sehinga mau melaksanakan perintah-Nya. ${ }^{2}$ Hukum dakwah adalah wajib a'in, dalam arti wajib bagi setiap muslim untuk berdakwah sesuai dengan apa ayang ia ketahui, sama halnya juga seorang konselor yang memiliki tugas agar mampu merubah hidup seorang yang dinasihati sehingga seorang konselor juga secara tidak langsung ia telah berdakwah kepada seorang dengan keluhan yang dinyatakannya. Obyek dakwah dengan uruturutan kepada diri sendiri, keluarga, sanak keluarga dekat atau sanak famili, sebagian kelompok, agar memahami makna tauhid dan dua kalimat syahadat. ${ }^{3}$ kepada seluruh umat manusia, dan berdakwah juga dapat melalui media sosial agar dakwah yang kita sampaikan dapat diketahui khalayak ramai. ${ }^{4}$ Berdakwah perlu menggunakan metode, yaitu cara dakwah yang teratur dan terprogram secara baik seperti cara berdakwah syech yusuf al-makassari. ${ }^{5}$ agar maksud mengajak melaksanakan ajaran-ajaran agama Islam dengan baik

\footnotetext{
${ }^{1}$ Rubawati, E. (2018). Media Baru: Tantangan dan Peluang Dakwah. Jurnal Studi Komunikasi, 2(1).

2 Nawali, A. K. (2018). Hakikat, Nilai-Nilai Dan Strategi Pembentukan Karakter (Akhlak) Dalam Islam. Ta'lim: Jurnal Studi Pendidikan Islam, 1(2), 325-346.

${ }^{3}$ Sainuddin, I. H., S, Arsyam, M., \& Alwi, A. M. S. (2020, August 19). Pemahaman Makna Tauhid dan Dua Kalimat Syahadat. https://doi.org/10.31219/osf.io/g84vu

${ }^{4}$ Sainuddin, I. H., S. (2020, July 27). Dakwah di Era Sosial Media. https://doi.org/10.31219/osf.io/2jxny

5 Sainuddin, I. H., S, Arsyam, M., Wekke, I. S., \& Rajjako, A. (2020, August 24). Syekh Yusuf Al-Makassari; Pengembangan Masyarakat Islam. https://doi.org/10.31219/osf.io/mg8f6
} 
dan sempurna. Metode dakwahnya dengan Hikmah, Maw'izhah Hasanah, Berdiskusi atau Tukar Fikiran Dengan Cara Yang Baik, menyam-paikan sautu kisah, perumpamaan, tanya jawab, dan keteladanan yang baik.

\section{PEMBAHASAN}

\section{A. Definisi Dakwah}

Dakwah merupakan segala bentuk aktivitas penyampaian ajaran Islam kepada orang lain dengan berbagai cara bijaksana agar memahami dan mengamalkan ajaran Islam dalam semua lapangan kehidupan, maupun pelestarian lingkungan dalam implementasi dakwah. ${ }^{6}$ Berbagai cara bijaksana itu mestilah dilaksanakan dengan seperangkat ilmu yang dikenal sebagai ilmu dakwah.

\section{B. Bimbingan konseling}

Bimbingan dan Konseling adalah proses interaksi antara konselor dengan konseli baik secara langsung maupun tidak langsung dalam rangka untuk membantu konseli agar dapat mengembangkan potensi dirinya ataupun memecahkan permasalahan yang dialaminya. ${ }^{7}$

\section{Apakah konselor dibutuhkan di sekolah}

Konselor dibutuhkan untuk menyelesaikan masalah dari para siswa dan juga berperan dalam memandu siswa dalam mengarahkan minat dan bakat agar menjadi hal yang positif. Untuk menyelesaikan hal itu biasanya konselor memberikan tes psikologi. ${ }^{8}$ Layanan Bimbingan Konseling dibutuhkan oleh sekolah dan masyarakat. Untuk di tingkatan SMA biasanya Bimbingan Konseling dijadikan sarana konsultasi siswa untuk merencanakan jurusan perkuliahan yang akan dipilih hingga karier yang dicita-citakan. Sedangkan di masyarakat, Bimbingan Konseling diperlukan untuk memberi pemahaman terkait perilaku-perilaku negatif yang merugikan kehidupan baik sebagai individu maupun sebagai anggota masyarakat. Selain itu juga untuk memberikan layanan pendidikan bagi anak-anak jalanan, dan mengupayakan pencegahan atas kasus-kasus sosial lainnya.

\footnotetext{
${ }^{6}$ Alwi, A. M. S., Arsyam, M., Sainuddin, I. H., S, \& Makmur, Z. (2020, August 18). PELESTARIAN LINGKUNGAN SEBAGAI IMPLEMETASI DAKWAH BI AL-HAL DAN WUJUD KESADARAN MASYARAKAT. https://doi.org/10.31219/osf.io/vf6qm

7 Fatchurahman, M. (2018). Problematik Pelaksanaan Konseling Individual. Jurnal Bimbingan dan Konseling Ar-Rahman, 3(2), 25-30.

${ }^{8}$ El Fiah, R., \& Purbaya, A. P. (2016). Penerapan Bimbingan Belajar dalam Meningkatkan Hasil Belajar Peserta Didik di SMP Negeri 12 Kota Bandar Lampung Tahun Pelajaran 2015/2016. KONSELI: Jurnal Bimbingan dan Konseling (E-Journal), 3(2), 171-184.
} 


\section{Hubungan erat dakwah dengan konseling}

Hubungan dakwah dengan konseling sangatlah erat, ini dikarenakan tugas konselor yang harus memberi saran dan mengajak si konseli untuk mengubah pola pikir dan gerak gerik kehidupannya agar kehidupan kita berjalan dengan baik. ${ }^{9}$ Sedangkan dakwah artinya mengajak seseorang untuk berbuat dan berperilaku baik dan positif agar kehidupan yang dijalani seorang yang di dakwahi itu tentram. Jadi secara garis besarnya ialah apabila seorang konselor memiliki seorang konseli, maka pada saat itu juga seorang konselor dapat mendakwahi seorang konseli.

\section{PENUTUP}

1. Dakwah merupakan segala bentuk aktivitas penyampaian ajaran Islam kepada orang lain dengan berbagai cara bijaksana agar memahami dan mengamalkan ajaran Islam dalam semua lapangan kehidupan.

2. Bimbingan dan Konseling adalah proses interaksi antara konselor dengan konseli baik secara langsung maupun tidak langsung dalam rangka untuk membantu konseli agar dapat mengembangkan potensi dirinya ataupun memecahkan permasalahan yang dialaminya.

3. Konselor dibutuhkan untuk menyelesaikan masalah dari para siswa dan juga berperan dalam memandu siswa dalam mengarahkan minat dan bakat agar menjadi hal yang positif. Untuk menyelesaikan hal itu biasanya konselor memberikan tes psikologi.

4. Hubungan dakwah dengan konseling sangatlah erat, ini dikarenakan tugas konselor yang harus memberi saran dan mengajak si konseli untuk mengubah pola pikir dan gerak gerik kehidupannya agar kehidupan kita berjalan dengan baik.

${ }^{9}$ Prasetya, M. A. (2015). Korelasi Antara Bimbingan Konseling Islam dan Dakwah. Addin, 8(2). 


\section{DAFTAR PUSTAKA}

Rubawati, E. (2018). Media Baru: Tantangan dan Peluang Dakwah. Jurnal Studi Komunikasi, 2(1).

Nawali, A. K. (2018). Hakikat, Nilai-Nilai Dan Strategi Pembentukan Karakter (Akhlak) Dalam Islam. Ta'lim: Jurnal Studi Pendidikan Islam, 1(2), 325-346.

Sainuddin, I. H., S, Arsyam, M., \& Alwi, A. M. S. (2020, August 19). Pemahaman Makna Tauhid dan Dua Kalimat Syahadat. https://doi.org/10.31219/osf.io/g84vu

Sainuddin, I. H., S. (2020, July 27). Dakwah di Era Sosial Media. https://doi.org/10.31219/osf.io/2jxny

Sainuddin, I. H., S, Arsyam, M., Wekke, I. S., \& Rajjako, A. (2020, August 24). Syekh Yusuf AlMakassari; Pengembangan Masyarakat Islam. https://doi.org/10.31219/osf.io/mg8f6

Alwi, A. M. S., Arsyam, M., Sainuddin, I. H., S, \& Makmur, Z. (2020, August 18). PELESTARIAN LINGKUNGAN SEBAGAI IMPLEMETASI DAKWAH BI AL-HAL DAN WUJUD KESADARAN MASYARAKAT. https://doi.org/10.31219/osf.io/vf6qm

Fatchurahman, M. (2018). Problematik Pelaksanaan Konseling Individual. Jurnal Bimbingan dan Konseling Ar-Rahman, 3(2), 25-30.

El Fiah, R., \& Purbaya, A. P. (2016). Penerapan Bimbingan Belajar dalam Meningkatkan Hasil Belajar Peserta Didik di SMP Negeri 12 Kota Bandar Lampung Tahun Pelajaran 2015/2016. KONSELI: Jurnal Bimbingan dan Konseling (E-Journal), 3(2), 171-184.

Prasetya, M. A. (2015). Korelasi Antara Bimbingan Konseling Islam dan Dakwah. Addin, 8(2). 